\title{
手術七ル腎臟結核ノ統計的觀察(第1回報告)
}

\author{
日本赤十字邽上 病院外科

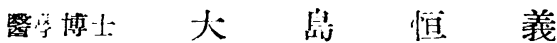 \\ 醫學士 永 井秦生 \\ Aus der urolog-chirurgischen Klinik des Rotenkrenz- Hospitrals zu Tokyr.
}

\section{Die statistische Beobachtung der operierten Nierentuberkulose.}

\author{
Von \\ Dr. 'Tsuneyoshi Oshima und Dr. Hurus Nag.i.
}

Die Gesamtzahl, die im Laufe von etwa 17 Jahren in unserer Klinik wegen Tuberkulose nephrektomierten Kranken, sind 128. Darunter haben wir 116 Fülle (12 Fälle wegen der nangelhaften Beschreibung des Protokolls ausgeschlossen). in dieser Statistik aufgenommen.

1) Die Statistik zeigt nach Geschlecht, Alter und erkrankter Seite die folgenden Ziffern :

Geschlecht; Männer 67 Fülle (57.7\%), Frauen 49 Fälle (42.3\%).

Alter; Am häufigsten im Alter zwischen 20 urd 20 Lebersjabren. Der jüugste Fall war im 9. Lebensjahr und der ältesta im 58. Lebensjahr.

Erkrankte Seite; Die linke Seite (60.4\%) hïufiger als die rechte (39.6\%).

2) In Bezug auf An:sthesie bei der Operation verwandten wir früher die Leiturgsan̈̈sthesie an den XII. Interkostal- und Jumbalnerven. Doch wegen Unsicherheit der Wirkung der obengenannten Methode haben wir in den letzten 4 Jahren fast alle Nephrektomie unter Lumbalan̈̈sthesie zwischen dem I. und II. Lendenwirbol ausgefihrt. Durch letztere Methode war das Resultat viel befriedigender.

3) Die Bestrebung zur frühzeitigen Vernarbung der Operationswunde glauben wir am notwendigsten, besonders bei solchen Kranken wie Nierentuberkulose, weil bei dieser die allgemeine diäthetische Kur nach der Operation die 
ausschlaggebendste Wichtichkeit hat. Wir versorgen die nephrektomierte Wunde unter Ricksicht, die sekundäre Infektion der eng geschlossenen Wunde möglichst zu verhüten. Unter diesen Vorsichtsmassregeln konnten wir in den letzten 6 Jahren ungefähr 50\% aller Fälle in 2 Wochen und $78 \%$ in I Nonate ausheilen.

4) Uंber 74 Fälle, die wir nach untersuchten oder die Prognose schriftlich verfolgen konnten, ergibt die Statistik folgendes:

am Leben geblieben 44 Fälle $(59.5 \%)$

vollständig ausgeheilt

31 Falle (41.9\%),

gebessert

10 Fälle (13.5\%),

nicht gebessert

gestorben

30 Fälle (40.5\%),

3 Fälle ( $4.1 \%)$,

Operationstod (innerhalb I Monate nach Operation)

9 Fälle $(12.2 \%)$

(7.1\% unter 116 Füllen)

Tod innerhalb 6 Monaten nach Operation

5 Fälle $(6.8 \%)$

Tod über 6 Monate nach Operation

14 Fälle (18.9\%)

unklar

2 Fille ( $26 . \%)$,

Nach der Statistik von 35 Fällen, bei denen nach der Operation iber 4. Jabre. vergangen sind, zeigen die Ziffern folgendes:

am Leben geblieben

19 Fälle $(54.3 \%)$

vollständig ausgeheilt

13 Fälle $(37.1 \%)$,

gebessert

3 Fälle $(8.6 \%)$,

nicht gebessert

0

gestorben

16 Fälle (45.7\%).

5) Es ist ganz bemerkens wert dass die Zeitdauer, welche vom ersten Beginn der subjektiven Beschwerde bis zur Operation verstrichen im allgemeinen beim vollständig ausgeheilten Fall viel länger im Verhältnis zu derselbeu beim. verstorbenen ist.

Nach dieser Tatsache scheint es uns annehmbar zu sein, dass die Prognose der Nephrektomierten wegen Tuberkulose meist von den Virulenzgrad der Krankheitserreger und der Widerstandkraft des betreffenden Patienten beherrscht werden.

第 1 章 緒言

第 2 竟 手術患者二就テ

第 1 項 性站二患側

第 2 項 年踤会

第 3 章 手術二就テ

第 1 項 虫侧診糍法及機能檢查
次

第 2 項手術方法

第 3 項 梳醉

符 4 章 手術後ノ經過二就テ

第 1 項 手術㓱 /治癒

第 2 項 手術患者/踭後

其, 1 生存 例 
其, 2 死亡 例

其， 3 全治例卜死亡例卜ノ比較
第 5 管 結

言

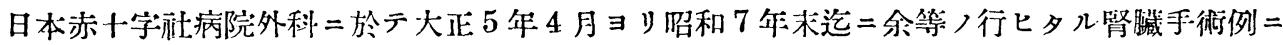

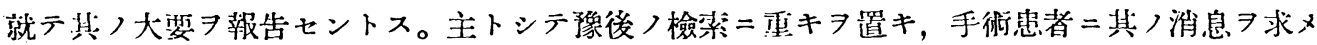

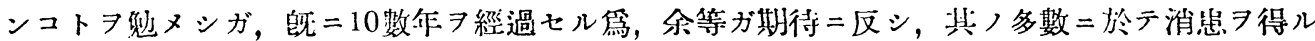

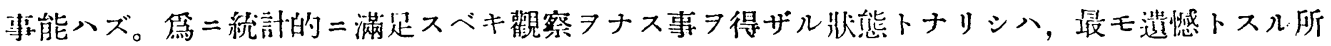
ナリ。

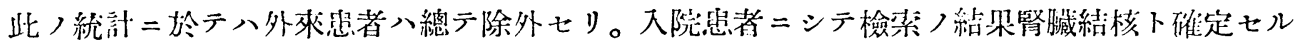

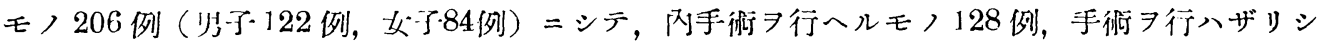
モノ78例ナリ。更二手術舁者 128 例中記載不朋ノモノ11例及摘饪不能ナリシモノ 1 例アルラ以

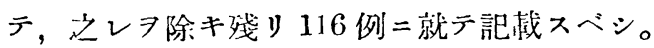

\section{第 2 章手采患者二就テ}

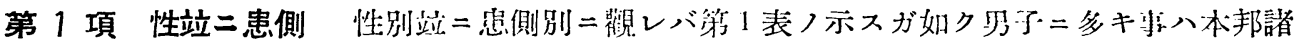

第 1 表

\begin{tabular}{c|c|c|c}
\hline 性別 & 右 & 左 & 計 \\
\hline 男 & $\begin{array}{c}28 \\
(24.1 \%)\end{array}$ & $\begin{array}{c}39 \\
(33.6 \%)\end{array}$ & $\begin{array}{c}67 \\
(57.7 \%)\end{array}$ \\
\hline 女 & $\begin{array}{c}18 \\
(15.5 \%)\end{array}$ & $\begin{array}{c}31 \\
(26.8 \%)\end{array}$ & $\begin{array}{c}49 \\
(42.3 \%)\end{array}$ \\
\hline 計 & $\begin{array}{c}46 \\
(39.6 \%)\end{array}$ & $\begin{array}{c}70 \\
(60.4 \%)\end{array}$ & 116 \\
\hline
\end{tabular}

芜ノ統計トー致スレドモ，毟側二於テハ一般 二左右大ナル差ヨ兒ズト云ハレ，又ハ多少右 ニ多シト云ハルレドモ, 余等ノ例 $=$ 於テハ著 シク龙側二多キ事习特異トス。而シテ更二性

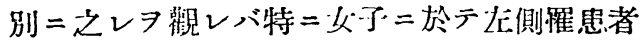
著シク多シ。

第 2 項 年齢 余等ノ例二於ヶル最長年 者ハ58歲ナリ。20歲ヨリ30藏迄ガ最多數ニシ テ 40 歲以上二其ノ數 7 減ズルコト諸家ノ統計 卜何等異ナルコトナシ。最少年者八 9 歲ノ女兒ナリ。
第 2 表

\begin{tabular}{|c|c|c|c|}
\hline 作嚙合 & 男 & 女 & 計 \\
\hline $1-10$ & 0 & 1 & 1 \\
\hline $11-15$ & 1 & 1 & 2 \\
\hline $16-20$ & 12 & 6 & 18 \\
\hline $21-25$ & 17 & 14 & 31 \\
\hline $26-30$ & 18 & 12 & 30 \\
\hline $31-35$ & 9 & 9 & 18 \\
\hline $36-40$ & 4 & 2 & 6 \\
\hline $41-45$ & 1 & 4 & 5 \\
\hline $46-50$ & 3 & 0 & 3 \\
\hline $51-55$ & 1 & 0 & 1 \\
\hline $56-60$ & 1 & 0 & 1 \\
\hline $61 \longrightarrow$ & 0 & 0 & 0 \\
\hline 計 & 67 & 49 & 116 \\
\hline
\end{tabular}


第 1 項 患側揨斷法及機能檢查。總婜臟機能檢李法二就テハ全部= Phenolsulphonph-

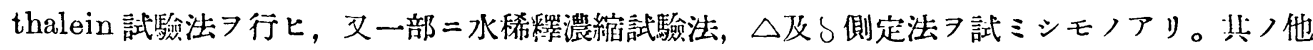
患側ノ診斷二對シテハ譄胱鏡檢查，色素排泄試驗，輸尿管「カテーテル」等习行ヒタルコトハ

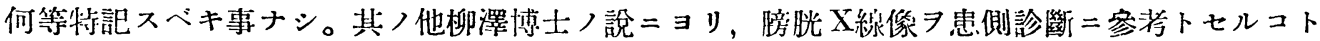

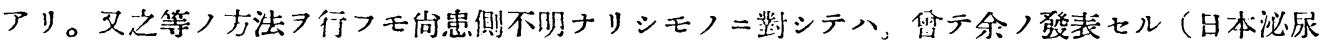

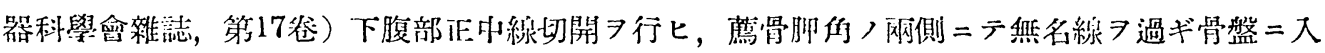
ラントスル丽側輸疗管ヨ觸沴シ，其ノ肥厚ノ如何ニョリテ之レヨ讨定セントスル方法ヨ採リシ

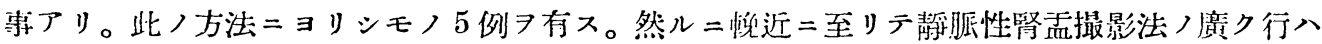

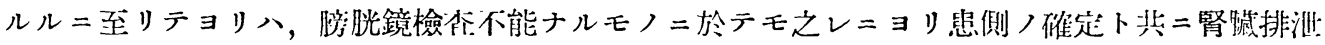
機能ノ如何ヨ知ルコトラ得ルニ至リシラ以テ, 上記ノ如ク Cystogram 又八余ノ述ベシ如キ手

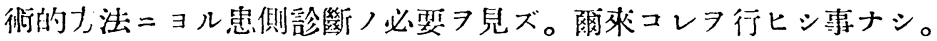

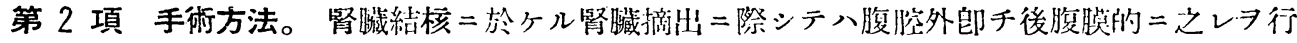

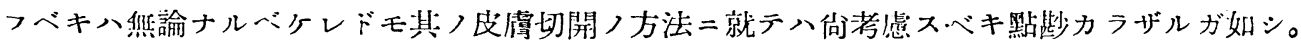
余八初メ多クノ場合ニ於テ Bergmann-Israel氏 $ニ ヨ ル$ 刹行腰部切開习行ヒタレドモ，近年（西 㷊1930年) Lexer 氏ガ一種ノWinkelschnitt 7 發表セル

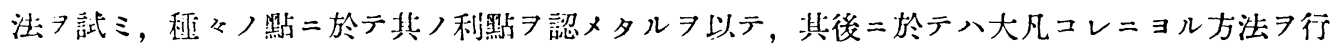
ヒタリ。Lexer比發表セルモノ八所謂 Fritz König 氏ノ方法トシテ記械七ラレタルモノト

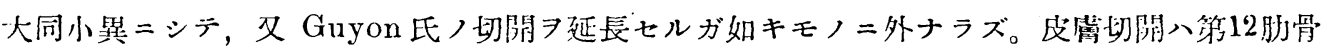

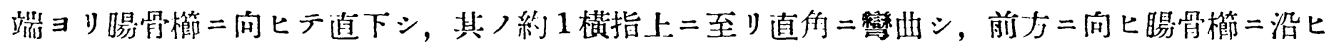

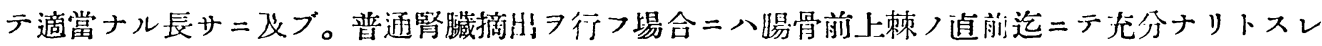

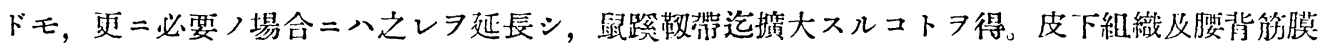

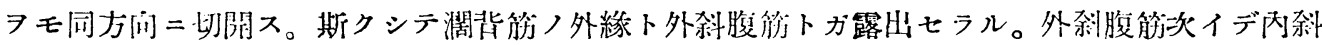

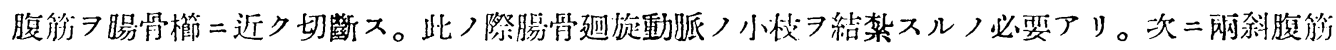

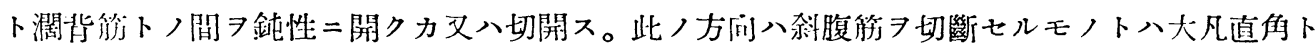
ナル。切斷七ラレタル兩斜腹筋

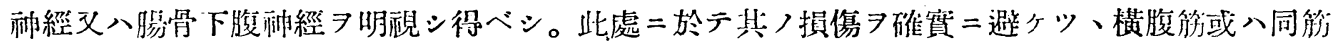
膜习切開ス。其,方向八皮膚切開ノ方向卜簧ナリ，斜二後上方ヨリ前下方二间フモノトス。斯

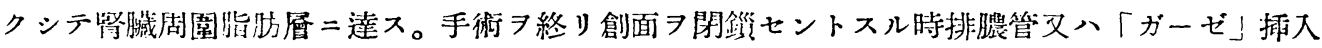

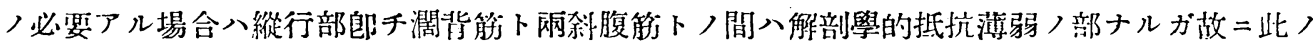

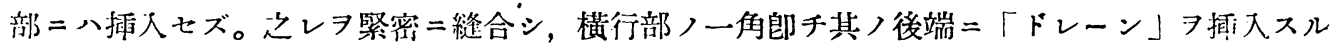

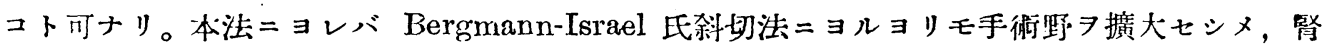

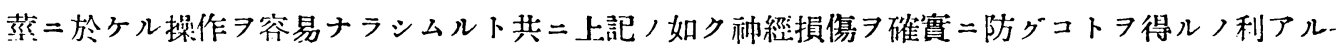


ᄏ以テ余八此ノ方法 7 行ヒ始メショリ以來 3 年間 $=$ 行ヒシ凡ソ 40 例二於テハ總テ本切開 $=ヨ レ$

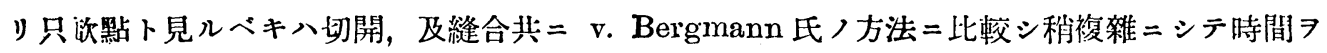
要スル慗ナリトス。

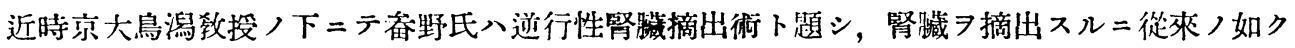

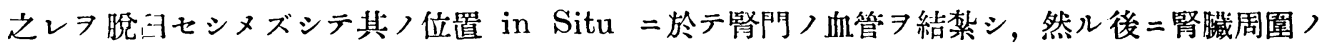
剩離ヨ行ヒ，之レヨ摘出スル事ノ有理ナル尹述ベタリ。此ノ Ligatur der Nierengefässe ohne Luxation 八兓二腫䓪=於テ Czerny, Trélat. Grégoire 氏等又結核ニ於テ Chevassu氏 ニョリ指導セラレ, 新シキ提案ニハ非ラザルモ極メテ合理的ナルベク, 若シ操作ガ困難ナシニ 行ハレ得ルナラバ推賞スベキモノナルベシ。之等ノ諸氏八第10枷骨ト腋㸗線トノ交仪點ヨリ暘

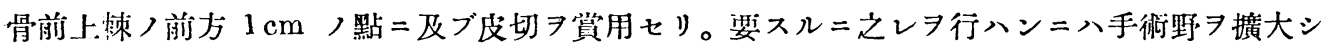
腎蕉部》允分二明視スルノ要アリ。斯カル場合ニ八上記 Lexer 氏 切開ニヨレバ水平部ヨ正中 線二向ヒテ延長スルコトヨリ充分ナル腔ヨ得ルヨ以テ有利ナリトス。

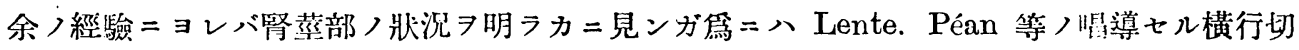

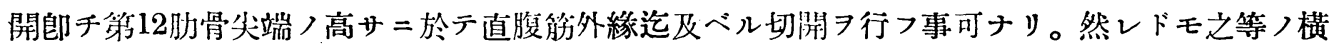

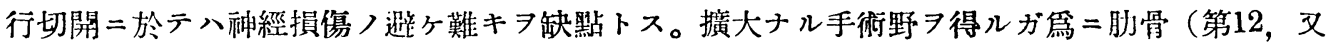
八第11）ヨ切除スル者アレドモ，余八現今二於テ其ノ必要ナキモノト考ヘツツアリ。余八 3 例 ニ於テ之レア行ヒシ事アリ。胁骨切除ノ如キ八何等困難ナク一少時ニシテ行ヒ得ル手技ナルガ

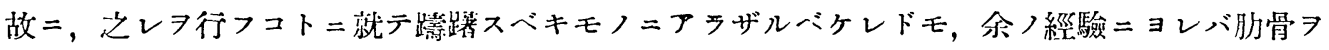

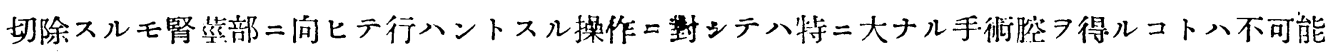
ナルガ如シ。

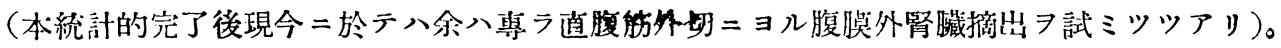

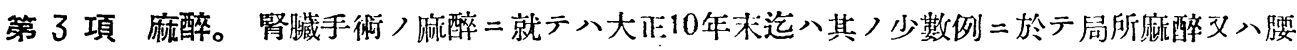

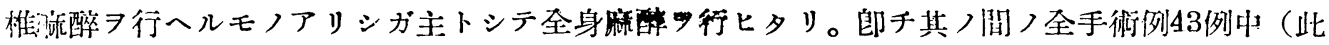

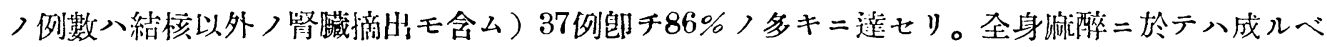

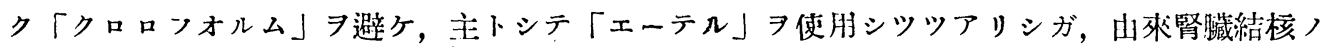

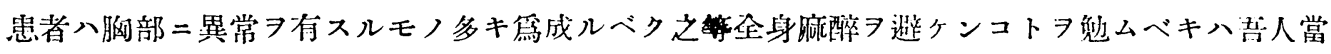
然つ責務ナルベシト考へ，大正11年以桃一般外科=於テ局所湤醉ノ使用盛ナル二及ビ，分八腎

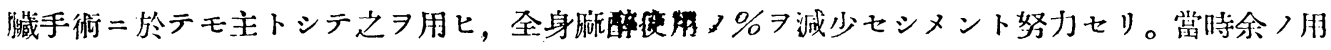

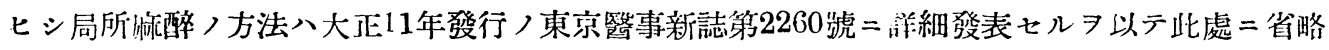

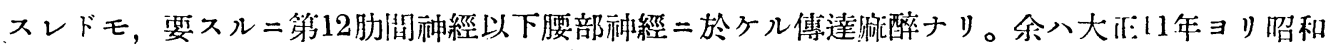

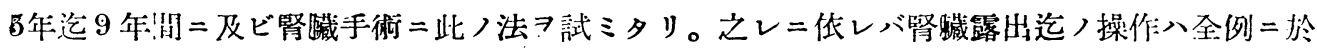

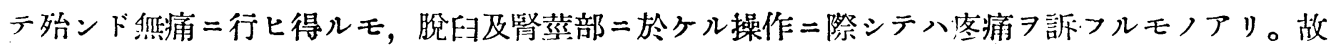


二其ノ開ノミ少量ノ「ェーテル」(20cc以內ナルラ常トス) ヨ用フルノ止ム

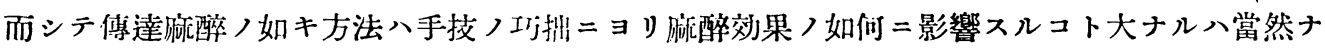

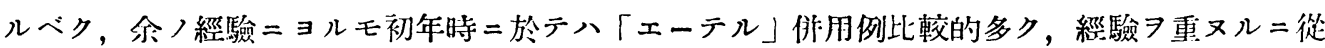
ヒテ次第ニ之レヨ減少セシメタリトイへドモ, 終二吾人所期ノ域 $=$ 達スル事

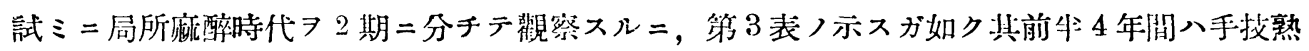

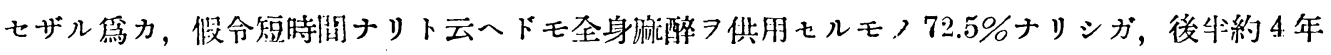

第 3 表

\begin{tabular}{|c|c|c|c|c|c|}
\hline 拘 & & 間 & 全麻ナキモノ & 全麻俳洞 & 视忽數 \\
\hline \multirow{2}{*}{ 间所麻醉约 } & $\begin{array}{l}\text { 息 } \\
\text { 至 }\end{array}$ & $\begin{array}{l}\text { 大正11筷 } \\
\text { 大正14年 }\end{array}$ & $\begin{array}{c}11 \\
(27.5 \%)\end{array}$ & $\begin{array}{c}29 \\
(72.5 \% \text { \% }\end{array}$ & 40 \\
\hline & 自 & $\begin{array}{l}\text { 大正 } 15 \text { 年 } \\
\text { 炤和 } 4 \text { 年 }\end{array}$ & $\begin{array}{c}31 \\
(50.8 \%)\end{array}$ & $\begin{array}{c}30 \\
(49.2 \%)\end{array}$ & 61 \\
\hline 腰鯌麻醉期 & $\begin{array}{l}\text { 岀 } \\
\text { 至 }\end{array}$ & $\begin{array}{l}\text { 炤和 } 5 \text { 年 } \\
\text { 炤和 } 7 \text { 年 }\end{array}$ & $\begin{array}{c}29 \\
(67.4 \%)\end{array}$ & $\begin{array}{c}14 \\
(32.6 \%)\end{array}$ & 43 \\
\hline
\end{tabular}

間二於テハ $49.2 \%=$ 減少 セシメ得タリ。余ノ經䮦 ニョレバ此ノ\%ヨ之レ以 上ニ減少セシムル事八困 難ナル尹感ゼシ爲, 炤和 5 年以後八現今本邦二於 テ腎臓手術二最モ多ク朋

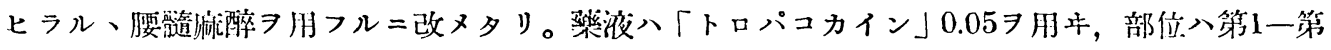

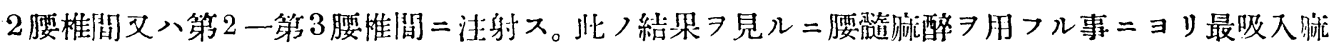
猝习減少セシメ得ルガ如シ。(第 3 表)

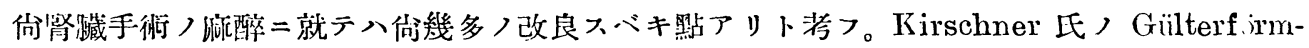
geinstellbare Lumbalanästbesie 又八v. Lichtenberg氏ノ方法等八試ムベキモノナルベシメ Evipan Natrium 静胍內注射等最便ナラント䓅フルモ米ダ之レラ試ミシコトナシ。

\section{第 4 章 手術後ノ經過二就テ}

第 1 項 手術創ノ治瘾。結核ニ於ヶル腎藏摘出創/治癒期䦌ニ就テハ諸芜ノ統計一様ナラ

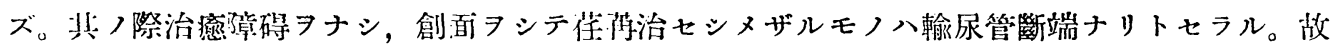

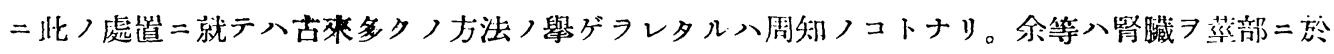
テ切斷シ終リタル後, 軨疗管ハ成ルベク肥厚スクナキ部マデ剥離シ，又下部二至ルモ肥厚低然

八腎倠ヨリ約 $30-15 \mathrm{~cm}$ ，部二於テ絹絲

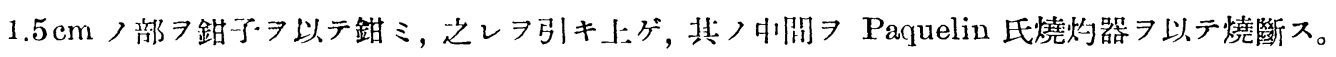

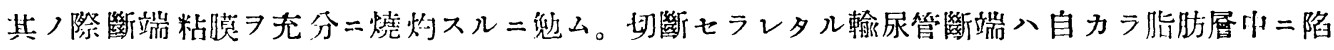

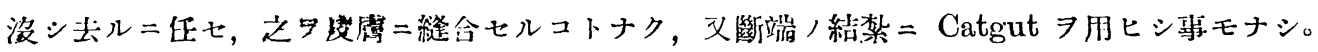

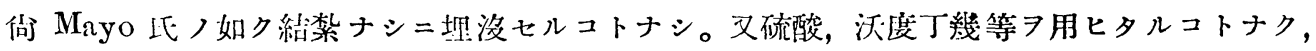

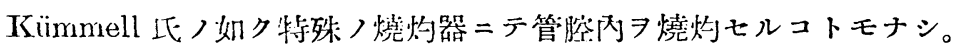

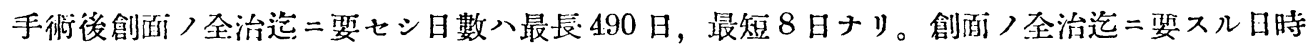

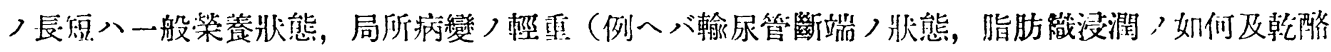


栐變性淋巴㟫ノ有無等）ノ如何ニョル事勿論ナルモ，余等ノ經驗ニョレバ主トシテ手術創ノ後 處置ノ如何ニヨルコト大ナルガ如シ。腎臟摘H後ニ於テハ大ナル創腔ヨ殘七ルニ拘ラズ一般二

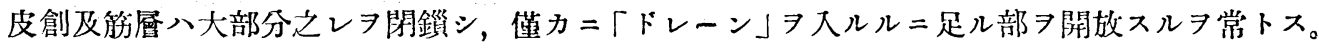
然ル二此ノ殘存創腔八腎脂肪膜ノ如キ脂肪組織二富メル部ナル 自明ノ理ナリ。故二治療法中一度此ノ比較的廣汎ナル手街創腔二感染 7 來サバ逐二創面八瘦孔 ノ状態トナリ月餘ニ涉リテ治セザルニ至ルモノ䓕ダ多シ。大正15年迄ハ特二之等ノ點二留意ス

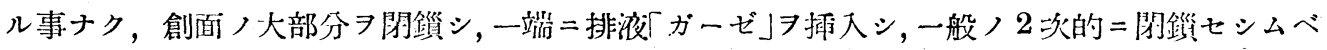
キ創面ト闹樣二考へ，之レヨ處置セリ。昭和 2 年以後八上記ノ顧虑ヨ以テ其方法 腔二挿大七ル「單ガーゼドレーン」フ48-72時間後二除去セル後八一切創腔フ觸ルル事ナク, 即

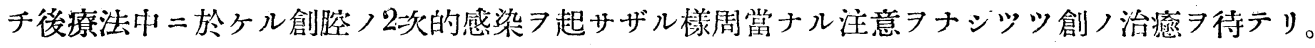

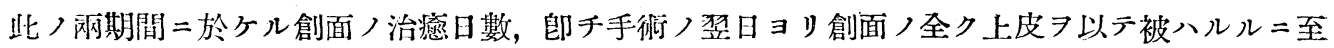

第 4 表

\begin{tabular}{|c|c|c|c|c|}
\hline 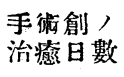 & \multicolumn{2}{|c|}{$\underset{(45 \text { 例 })}{\text { 大正 }} 5$} & \multicolumn{2}{|c|}{$\begin{array}{l}\text { 昭利 } 2-7 \text { - } 71 \text { 例) }\end{array}$} \\
\hline 2 凮 & $\left(7.2^{2} \%\right)$ & \multirow{3}{*}{$\begin{array}{c}11 \\
(42.3 \%)\end{array}$} & $\begin{array}{c}24 \\
(48 \%)\end{array}$ & \multirow{3}{*}{$\begin{array}{c}39 \\
(78 \%)\end{array}$} \\
\hline 20日 & 5 & & 9 & \\
\hline 30 日 & 4 & & 6 & \\
\hline 40 日 & \multicolumn{2}{|l|}{1} & \multicolumn{2}{|l|}{4} \\
\hline 50 日 & \multicolumn{2}{|l|}{3} & \multicolumn{2}{|l|}{1} \\
\hline 100日 & \multicolumn{2}{|l|}{7} & \multicolumn{2}{|l|}{4} \\
\hline 200日 & \multicolumn{2}{|l|}{2} & \multicolumn{2}{|l|}{0} \\
\hline $\begin{array}{l}200 \text { 日 } \\
\text { 以上 }\end{array}$ & \multicolumn{2}{|c|}{$2\left\{\begin{array}{l}288 \text { 旦 } \\
360 \text { 旦 }\end{array}\right.$} & 2 & $\begin{array}{l}270 \text { 日 } \\
490 \text { 日 }\end{array}$ \\
\hline 計 & \multicolumn{2}{|c|}{26} & \multicolumn{2}{|c|}{50} \\
\hline
\end{tabular}

大正 5 -15年45例中創 7 持于テ退院シ，其ノ後經 渦不明ナルモ/ 6 例及死亡セル13例八㫮創 7 有七 ル・ラ以テ之レヨ省キ殘り 26 例二就テ表示ス。 昭和2-7作71例巾死亡例 L 例其/他創面 7 有 ルママ退院シ，其ノ後經渦不明ノモ>15例及記載 /明䁻ナラザルモノ 5 例計 21 例 ヨ除ヶル 50 例二就 テ表示ス。
ルマデノ日數习示セバ第 4 表ノ如シ。

之レニ依リテ見レバ前牛期ニ於テハ2 週間內二治癒セルモノ $7.7 \%$ ナル = 後坐期二於テハ $48 \%$ トナリ，1 1 ケ以内 二治癒七ルモ/前体期ニ於テハ $42.3 \%$ ナ ル 對シ，後牛期二於テハ $78.0 \%=$ 文べ リ。後牛期ノモノ八 1 例 490 日ニシテ末 治ノモノアルモ之レハ一旦治瘺七ル後退。 院シ, 其ノ後自潰シ, 地方ノ醫師 $=ヨ$ リ 治療ア受ケツッアルモノナリ。故二此ノ .1例 7 除キ前牛期後牛期 $=$ 就テ治瘾二至 ル平均日数フ求ムレバ次ノ如シ。

前牛期……72.4日, 後斗期……3 30.8 日。

而シテ前本期ニテハ死亡七ル13例皆創 末治ナリシモノナルガ故二數字八前半二 於テ更二增扠スれノト考へザルバカラ ズ。

余等ノ例二於テハ退院後ノ消息习詳二 セルモノ比較的少ナキヨ以テ，此ノ數字ヨ以テ他ノ諸家ノモノト比較シ，其ノ成績

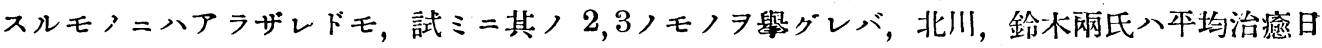
數 3 ケ月ナリト云フ。然レドモ平均數八全數中數例長期二涉リテ治瘾セザリシモノアル時八非 
常ナル差違ヨ生ズルモノナルラ以テ此ノ數ハシバラク措キ, 1 ケ月以內ニ治セルモノヨ諸家報 告中ョリ檢出スル $=$, 北川, 鈴木氏等八 31 例中 5 例 $(16.1 \%)$, 高橋, 尾關氏等八 130 例中15例 $(11.5 \%)$ 等ニシテ志賀氏ノ統計八治瘾期間最モ短カキガ如ク 119 例中約 $47.9 \%$ ケ月以內

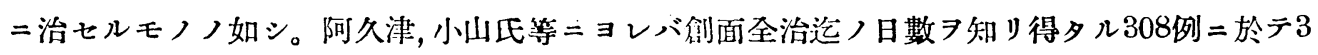
ケ月以內 =治瘾七ルモノ $51 \% ， 3$ ケ以上 6 月以內二治瘾七ルモノ $20 \% ， 1$ ケ年以內ノモノ 20 \%弱户數へ，更二同氏所揭ノ表二就テ見ル = 308 例中1ヶ月以队二治セルモノ4例ナルガ如シ。

上記ノ如ク余等ガ後牛期二試ミア現今二更ベルガ如キ創面 八腎臟ノ他ノ疾患例人バ腫瘍及水腫ノ如キ㶵菌的ナル疾患二就テハ何等㲘念スベキ點ナク。之 等 $=$ 對シテ真ノ第期 1 癒合ヨナス

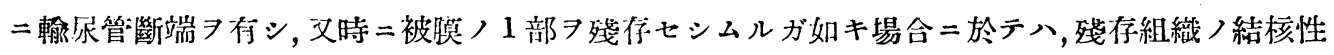

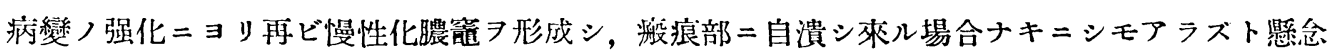

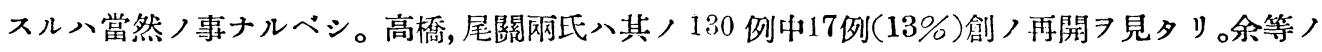
例二於テモ 5 例二於テ 1 ケ月乃至 3 年後 $($ 多クハ 9 ケ月以內 $)=$ 般痕部二自潰シ來リ, 䉆二創面 7 擴大シ搔爬スルノ必要二迫マラレタリ。內 4 例八小時日ニシテ全治シ，殘ル 1例八前記 490 日

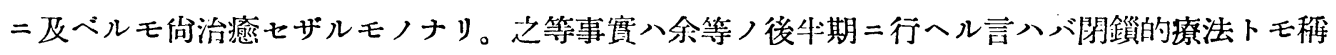
スベキモノノ缺點ナルベシ。然レドモ之等自潰シ來ルモノ八僅二其ノ 1 小部二過ギザル 余等八今日上記方法ヨ採リ, 成ベク早期二創西

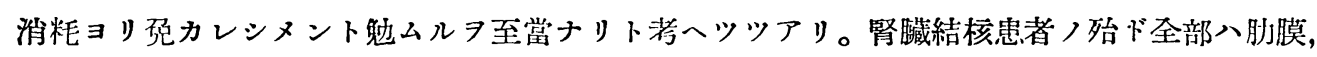

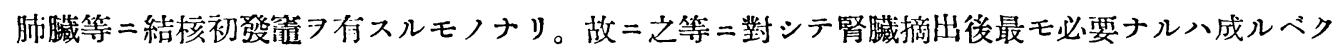

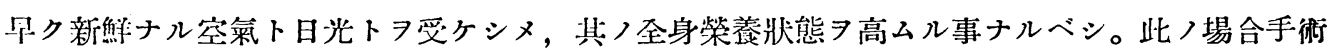
創ガ荏阵トシテ治セザル事長キ二及ババ，日ßノ繃帶交換ニョル蛋白消失アル外運動入浴ノ自

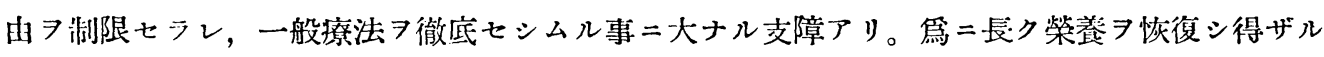
八明ナルベシ。之等ノ點ヨリ見テ成ルベク卧ク創面ヨ治セシムル事八相等重要つ事ナリト信ズ。

更二余等ハ多クノ監臟絬核腎歲摘出後二於テ, 脂肪組織二肉腿的ナル病變ナキ場合二於テハ

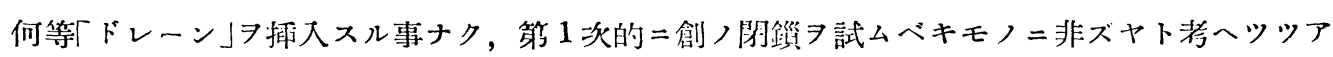
リ。可傅染性ナル輸尿管斷端

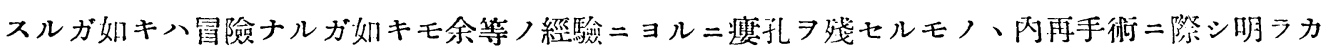

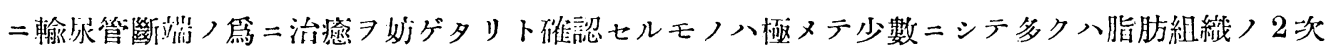

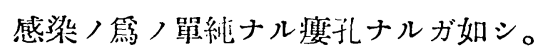

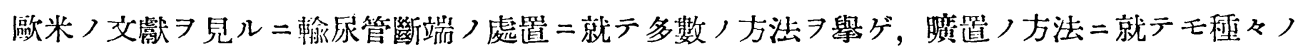
提案アリ。原则トシテ䡕尿管斷端ノ皮創縫着ヨナスモノアルハ余ノ不思議二感ズル所ナリ。前記 疿痕垶二自溃シ來レル 5 例二就テ見ルニ余ノ自カラ治療七ル 4 例ニ於テハ單純ナル切開二ヨリ 
少時日ニデ治癒シタルガ故二，斷端ノ結核ニ起因スルモノト考入得ザルガ如ク寧ロ脂肪組織又 八附近ノ淋巴腺結核琶ノ化膿ニョルモノナラント想像シツツアリ。上記ノ如クナルガ故二結核 腎摘出後ノ創面八第 1 期癒合 二於テ見ルモ「ドレーン」除去後創面八何等異常ナク，治癒スルモノ多キガ故二之等ノ「ドレ ーン」ノ多クハ埥用ナルモノヨ挿大シツツアルニ非ズヤト考ヘツッアリ。然レドモ輸尿管斷端

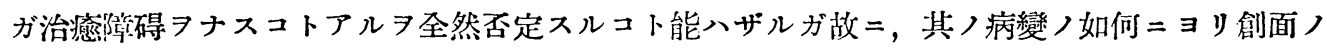
處㯰

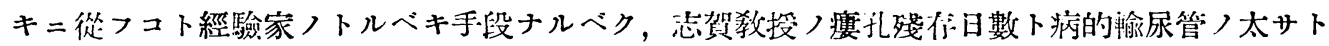
つ關係ヨ數字ヨ以テ示サレタルハコノ意味ニ於テ甚监重ナル材料ナリト考つ。

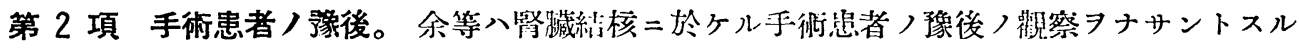
コトヨ本稿ノ主ナル目的ノ1ツトセルモノナリシガ，手術總數 128 例中腎獩摘出不能ナリシモ ノ1例，記載不朋ナルモノ11例 7 除キ 116 例二就テ其ノ消息 7 求メタル二住所不明ナルモノ 13 例，返信ナキモノ29例ニシテ僅カ $=74$ 例 $(63.8 \%)=$ 就テ其ノ消息ヨ冰メ得タル二過ギズ。殊 二吾人ノ知ラント欲スル10年以上ヨ經過セルモノニ渻息ノ不明ナルモノ多カリシハ最モ遺憾卜 スル所ナリ。74例中生存者 44 例 $(59.5 \%)$ 死亡者 30 例 $(40.5 \%)$ ナリ。

其ノ 1 生存例 生存者 44 例二就テ其ノ豫後ノ判定 7 全治, 輕快, 未治二區別セリ。

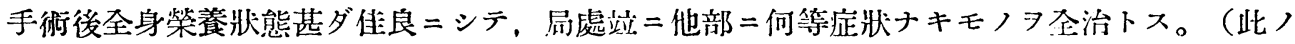
冈尿ノ檢植ヨナシ得シモノト然ラザルモノトアリ）尿ノ檢烋ヨナセルモノニ於テハ何等局處症 状ヨ訴へズ，尿清澄ナルモノニ於テモ「硫基サルチール睃」二桖ク僅カ二發見シ得ル蛋白ト，

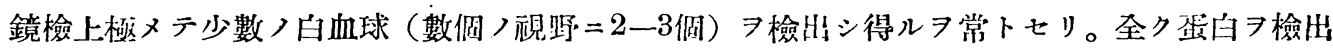

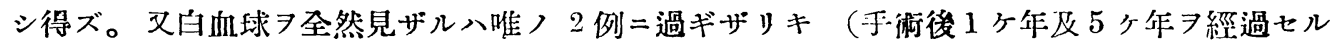

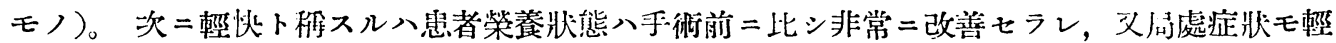
快シタレドモ，未来全治二至ラズ，尿中二蛋白少量

第 5 表

\begin{tabular}{|c|c|c|c|c|c|c|c|c|c|c|c|c|}
\hline \multirow{2}{*}{ 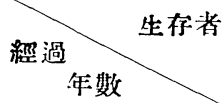 } & \multicolumn{3}{|c|}{ 生存者例 } & \multicolumn{3}{|c|}{ 全 治 例 } & \multicolumn{3}{|c|}{ 整 炏 例 } & \multicolumn{3}{|c|}{ 㭅 治 例 } \\
\hline & 男 & 女 & 計 & 男 & 女 & it & 男 & 女x & 郭 & 男 & 女 & 計 \\
\hline $1 / 2$ 迄 & 2 & 1 & 3 & 1 & 0 & 1 & 1 & 1 & 2 & 0 & 0 & 0 \\
\hline $1 / 2-1$ & 3 & 3 & 6 & 3 & 2 & 5 & 0 & 0 & 0 & 0 & 1 & 1 \\
\hline $1-2$ & 6 & 4 & 10 & 5 & 1 & 6 & 1 & 2 & 3 & 0 & 1 & 1 \\
\hline $2-3$ & 4 & 2 & 6 & 2 & 2 & 4 & 1 & 0 & 1 & 1 & 0 & 1 \\
\hline $3-4$ & 2 & 1 & 3 & 1 & 1 & 2 & 1 & 0 & 1 & 0 & 0 & 0 \\
\hline
\end{tabular}

リ。最後二米治卜䊈ス ル八手衔前二比シ全身

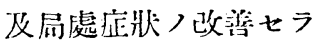
レズ尿ノ所光文同ジク 㭙二血瓜現ルガ如キ7 云フ。

之等ニ從ヒテ上記44 例 7 分類シ, 且其八手 術後經過年數 7 表示ス 


\begin{tabular}{|c|c|c|c|c|c|c|c|c|c|c|c|c|}
\hline $4-5$ & 0 & 3 & 3 & 0 & 3 & 3 & 0 & 0 & 0 & 0 & 0 & 0 \\
\hline $5-6$ & 2 & 3 & 5 & 2 & 2 & 4 & 0 & 1 & 1 & 0 & 0 & 0 \\
\hline $6-7$ & 0 & 2 & 2 & 0 & 2 & 2 & 0 & 0 & 0 & 0 & 0 & 0 \\
\hline $7-8$ & 1 & 1 & 2 & 1 & 0 & 1 & 0 & 1 & 1 & 0 & 0 & 0 \\
\hline $8-9$ & 1 & 2 & 3 & 0 & 2 & 2 & 1 & 0 & 1 & 0 & 0 & 0 \\
\hline $15-16$ & 1 & 0 & 1 & 1 & 0 & 1 & 0 & 0 & 0 & 0 & 0 & 0 \\
\hline 計 & 22 & 22 & 44 & 16 & 15 & 31. & 5 & 5 & 10 & 1 & 2 & 3 \\
\hline $\begin{array}{l}\text { 生存者 } 44=\text { 對 } \\
\text { ス }\end{array}$ & & & & \multicolumn{3}{|c|}{$70.5 \%$} & \multicolumn{3}{|c|}{$22.7 \%$} & \multicolumn{3}{|c|}{$6.8 \%$} \\
\hline $\begin{array}{l}\text { 消息制明七ル } \\
74=\text { 對スル\% }\end{array}$ & \multicolumn{3}{|c|}{$59.5 \%$} & \multicolumn{3}{|c|}{$41.9 \%$} & \multicolumn{3}{|c|}{$13.5 \%$} & \multicolumn{3}{|c|}{$4.1 \%$} \\
\hline
\end{tabular}

レバ第 5 表ノ如シ。

9 年以上ヨ經過七ル モ)八約16年，1例 7 除ク外皆無ナルハ此, 期間ノモノ八大让12年 關東大震桨以前ノモノ 二屬シ, 通信不能ナリ シモノ多數二_ヒレル關 係モアルコトナラシト 考フ。上訅約 16 年 7 經 過七儿患者八當時22藏

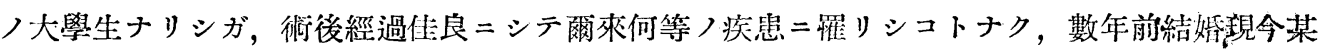
菜道會社二勤務シツツアルモノナリ。

全治例入渻息判明セ儿總數 74 例二對シ 31 例ニシテ $41.9 \%$ \% 歐来諸家) 報告 $(47.5-65.7$ $\%$ ）ト比シテ稍々劣リ，本邦諸家ノ報告 $(40-54.9 \%)$ ト略々一致ス。輕快例ハ 10 例ニシテ $13.5 \%=$ 當リ，未治例八女 2 例男 1 例ニシテ約 $4 \%$ リ。此ノ統計的數字八觀察ノ時期ノ長短 ニョリテ一樣ナラザルハ刎論ノコトニシテ，後述ノ死亡例ノ統計(第 9 表)二於テ示スガ如ク，

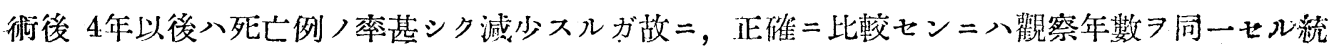
計ニ就テノミ行ハザレバ門意味ナルベシ。

第 6 表

\begin{tabular}{|c|c|c|c|}
\hline \multicolumn{2}{|c|}{ 例數 年數 } & $\begin{array}{l}2 \text { 年以上經渦七 } \\
\text { ルモ， } 48 \text { 例 }\end{array}$ & $\begin{array}{l}4 \text { 年以上經過七 } \\
\text { ルモ， } 35 \text { 例 }\end{array}$ \\
\hline & 亡 $(\%)$ & $23(47.9 \%)$ & $19(54.3 \%)$ \\
\hline & 存 $(\%)$ & $25(52.1 \%)$ & $5.7 \%)$ \\
\hline 生 & 全治 $(\%)$ & $19(39.6 \%)$ & $13(37.1 \%)$ \\
\hline & 輕快 $(\%)$ & $5(10.4 \%)$ & $3(8.6 \%)$ \\
\hline 存 & 未治 $(\%)$ & $1(2.1 \%)$ & $0<0$ \\
\hline
\end{tabular}

試ミ $=2$ 年及 4 年以上 7 經過七ル患者郎 于昭和 5 年來及昭和 3 年末迄二婜臟摘出 行ヒタル患者ノ渻息明ラカナルモノノミニ 就テ檢シ，總括シテ表示スレバ第 6 表 ’如 シ。

第 6 表 7 第 5 表卜比較スルニ多》ノ年月 フ經過セバ次第二生存者率习娍ジ, 從多テ 死亡者率 增加セル 7 見ルベシ。而シテ4

年以上ヨ經過七ルモノニ八米治及輕快者)數少ナク, 又一方二於テ死亡例中二示七ル（第 9 表 二示ス）ガ如ク死亡數八 4 年以後八著シク減少七ル モノ八死シ, 全治スルモノ八治シ，上記ノ數字八腎臟結核手術ノ遠達成績尹示スモノニアラズ ヤト考入。

其ノ2 死亡例 一般ノ統計二做ツテ術後 1 ケ月以內/死亡 手術死亡トナシ，6 ケ月以內 
7近期死亡トシ，65月以後 7 晚期死亡ト七バ，全死亡例 30 例八第 7 表ノ如ク分タル。

第 7 表

\begin{tabular}{|c|c|c|}
\hline $\begin{array}{l}\text { 死亡例 } \\
\text { 八分樤 }\end{array}$ & 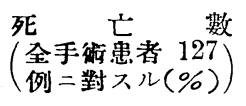 & $\begin{array}{l}\text { 消息制明七ル } 74 \\
\text { 例二對スル }(\%)\end{array}$ \\
\hline 手術死 & $9 \quad(7.1 \%)$ & $12.2 \%$ \\
\hline 近期死 & 5 & $6.8 \%$ \\
\hline 晚期死 & 14 & $18.9 \%$ \\
\hline 不明例 & 2 & $2.6 \%$ \\
\hline 妬 & 30 & $40.5 \%$ \\
\hline
\end{tabular}

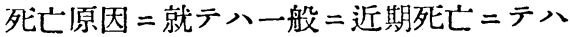
粟粒結核，腦膜炎多ク，晚期死亡二於テハ 肺結核，㛦妹腎絬核多シト云ハル。手術死 八9例 = シテ全手衔患者 127 例(全数 128 例 中揇出不能ノ 1 例 $习$ 除ク) =對シ $7.1 \%=$ 當 ル。死因 7 分類七バ高店二進行セル結核性 膿腫腎ノモノニシテ衰弱甚シク，手術ノ當 日及㫘日死亡七ルモノ 2 例, 尿毒症フ呈シ, 手術後 9 日及 22 日 ニシテ死亡セルモノ 2 例

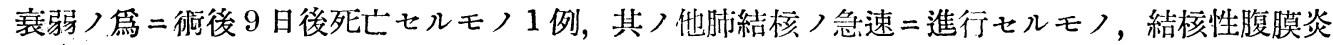
膿胸各 1 例，及不明ノモノ 1 例ナリ。近期死亡 5 例 7 消息判明ノ 74 例（手術全數二非ズ）＝對 シテ比ヨ求ムレバ $6.8 \%$ トナル腹膜炎 1 例，慢性腎臟炎 1 例，殘腎結核及全身結核 1 例，泌 尿生殖器結核高度トナリ襄弱ノ結果死亡セルモノ 1 例，衰弱 1 例ナリ。晚期死亡八14例ニシテ 74 例二對シテ比 求ムレバ $18.9 \%$ ケナル。之レフ疾患ニヨリ分類スレバ，姉妹腎結核 2 例，生

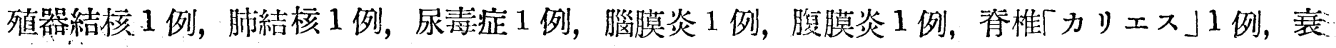
弱及不明 6 例ニシテ姉妹腎結侅 2 例中 1 例八 1 年, 1 例八 1 年 8 ケ月ニテ死亡七ルモノナリ。 尿毒症つ1 例八通信ニヨレバ 8 年後死亡セルモノナリ。恐ラク腎臟炎ナリシナラント想像ス。

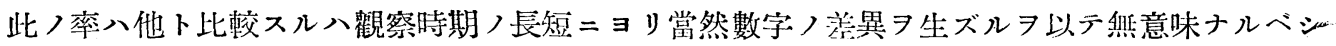
然レドモ本邦諸家ノ6 ケ月以後ノ死亡率卜比較セバ第 8 表ノ如シ。

\section{第 8 表}

\begin{tabular}{|c|c|c|}
\hline 報 告 者 & 死亡筷 & 發表年度 \\
\hline 谷野, 中村 & $33.7 \%$ & 1925 \\
\hline 中 川, 小池 & $30.4 \%$ & 1929 \\
\hline 北 川, 閣 部 & $17.6 \%$ & 1930 \\
\hline 志 & $8.6 \%$ & 1932 \\
\hline 高 橋, 尾關 & $11.2 \%$ & 1932 \\
\hline 阿久津, 小山 & $17.0 \%$ & 1933 \\
\hline 大島, 永井 & $18.9 \%$ & 1934 \\
\hline
\end{tabular}

第 9 表

\begin{tabular}{c|c}
\hline 死亡 年次 & 婏期死亡例 \\
\hline $1 / 2-1$ & 2 \\
\hline $1-2$ & 5 \\
\hline $2-3$ & 2 \\
\hline $3-4$ & 2 \\
\hline $4-5$ & 1 \\
\hline $5-6$ & 0 \\
\hline $6-7$ & 2 \\
\hline 7 以上 & 0 \\
\hline 計 & 14 \\
\hline
\end{tabular}


更二晚期死亡 7 其ノ年次二就テ分テバ第 9 表〉如シ。

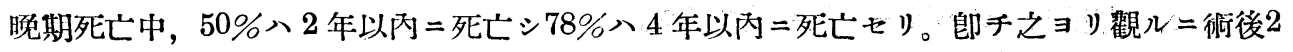
年ᄏ生存經過七ルモノノ死亡率八著シク減少シ，更= 2 年 過七ルモノ八死亡率八又一層減少スルモノ考へ得ルガ如シ。之等ノ點ョリ考フレバ $\mathrm{Kümmell}$ 氏ノ云へル術後 4 年間健康狀態ニアルモノハ之レヨ全治卜看做シテ可ナリト云フ二略々ー一致ス

其八 3 , 全治例卜死亡例卜ノ比較。 全治例卜死亡例ト 7 比較シテ觀祭スル $=$ 第10表二示ス ガ如シ。胸部二著明ナル合倣症ヨ有スルモ，死亡例二多キハ當然ナルベシ。著明デル絬核性

第10表

\begin{tabular}{c|c|c|c}
\hline \multicolumn{2}{|c|}{} & 全治31例 & 死亡30例 \\
\hline \multirow{2}{*}{ 性 別 } & 男 & 16 & 17 \\
\cline { 2 - 4 } & 女 & 15 & 13 \\
\hline \multirow{2}{*}{ 患側別 } & 男 & 20 & 16 \\
\cline { 2 - 4 } & 女 & 11 & 12 不明 2 \\
\hline \multicolumn{2}{l|}{ 胸部合侀症 } & 8 & 15 \\
\hline
\end{tabular}
腹膜炎ヨ合併セルモノ八手術ヨ行ハザルラ以テ之レニ入 ラズ。次二性別二就テハ一般二女子=於テ豫後ガ比較的 借良ナリト云へドモ,余等ノ例二於テハ大差ナク，患側別 二肸テハ統計上著シキ差異ア見ル事ナシ。唯注目スベキ 八初メテ自覺症狀ヨ生ゼショリ手術迄ノ時日ナリ。自覺 症狀ノ發七ショリ手琎迄ノ經過日數卜其豫後卜ノ關係 表示スレバ第11表ノ如シ。1 年以上經過セルモノ死亡例 6 例中 2 例八 $1-2$ 年ノモノ，4例八 $2-8$ 年=涉レルモ ノナリ。全治例 9 例二就テハ 2 例ハ $1-2$ 年ノモノ， 7 例ハ2-7年ノモノナリ。試ミ二自覺症狀

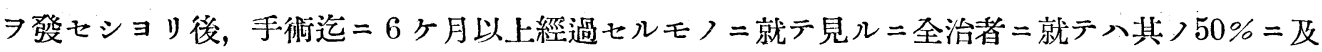
ビ死亡者ニ於ケル $34.5 \%$ 遙カ二淳駕セリ。

第 11 表

\begin{tabular}{|c|c|c|c|c|c|c|}
\hline & 1ヶ月以內 & 3 万月以 & 6 ヶ以内 & 1ヶ年以内 & 1ヶ年以上 & 計 \\
\hline 死亡 例(\%) & $\begin{array}{c}1 \\
(35 \%)\end{array}$ & $(24.1 \%)$ & $\begin{array}{c}11 \\
(37.9 \%)\end{array}$ & $\begin{array}{c}4 \\
(13.8 \%)\end{array}$ & $\begin{array}{c}6 \\
(20.7 \%)\end{array}$ & 29 \\
\hline 全 治 例(\%) & $\begin{array}{c}3 \\
(10.0 \%)\end{array}$ & $\begin{array}{c}4 \\
(13.3 \%)\end{array}$ & $\begin{array}{c}8 \\
(26.7 \%)\end{array}$ & $\begin{array}{c}6 \\
(20.0 \%)\end{array}$ & $\begin{array}{c}9 \\
(30.0 \%)\end{array}$ & $* *$ \\
\hline
\end{tabular}

*死亡 30 例小不明 1 例 7 除ク。

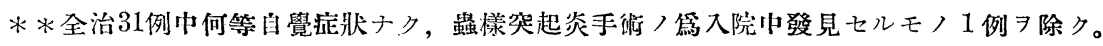

之等ノ點ヨリ考フル二大體二於テ菌ノ性爿，個人ノ體質及免疫成生ノ如何等 $=ョ リ$ 病變進行 㢑キモノニ於テ手術成績又佳良ナリト見ルベキモノナラント想像ス。

\section{第 5 章結論}

1）大䜣 5 年 4 月ヨリ昭和 7 年末迄二腎臟結核ニテ腎臟摘出 7 行へル患者 128 例中不明 12 例 7 除キ 116 例二就テ萑ルニ

$\mathrm{a}$ ，性别ニテハ女子 $(42.3 \%) \exists リ$ 男子 $(57.7 \%)=$ 多ク， 
b，患側別 $=$ テハ右側 $(39.6 \%) ヨ リ$ 左側 $(60.4 \%)=$ 多ク，

c，年齢別ニテハ $20-30$ 歲ニ最モ多シ。

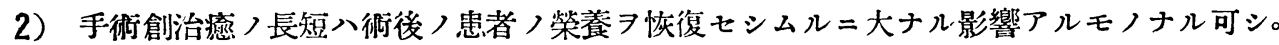

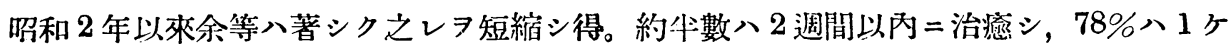

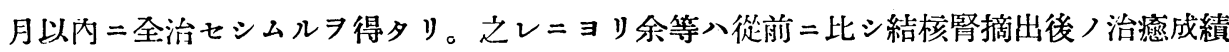
ヨ改善シ得ラルルノ理ナリト考つ。例數少ナキコト叉經過年數ノ相互二相違セル點ヨリ シテ成績 $コ$ 比較シ得ザルラ遺憾トス。

3）预後二就テハ其ノ消息ヨ求メ得タルモノ僅74例 $(63.8 \%)=$ 過ギザリシハ遗憾トスル處ナ ルモ之レニ就テ觀ルニ次ノ如シ。

$$
\begin{aligned}
& \text { 生存例……44例 }(59.3 \%) \text { 枯 治……31例 }(41.8 \%) \text {, } \\
& \text { 刺 快……10例 }(13.5 \%) \text {, } \\
& \text { 末 治……3 例 }(4.0 \%) \text { 。 }
\end{aligned}
$$

死亡例……30例 $(40.7 \%)$ 手術死……9 例 $(12.2 \%)(7.1 \% \cdots \cdots 116$ 例二對シ)，

$$
\begin{aligned}
& \text { 近期死……5 例 }(6.8 \%), \\
& \text { 晚期死……14例 }(18.9 \%) \text {, } \\
& \text { 不 明……2 例 }(2.1 \%) 。
\end{aligned}
$$

患側八豫後二關係ナク, 又性二就テ云へバ歐米諸家特 $=$ Wildbolz氏ノ統計 $=ヨ ル$ 男子. 八女子・二比シ柕後著シク不良ナリト云フモ余等ノ例八大差ナシ。統計的萑察ニヨリ手赶 後 4 年以上 7 經過七ルモノノ示ス數等八大凡碓定セル遠達成績

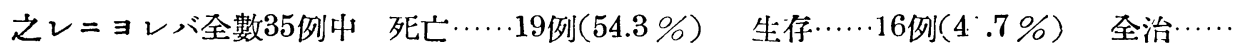
13例 $(37.1 \%)$ 輕快……3 例 $(8.6 \%)$ 未治……0 例。

4）自覺的症狀發セショリ手術迄ノ經過日數习見ル $=6$ ケ月以上ノモノ全治例 $50 \%$ ケシテ死 亡例 $34 \%$ リ。殊=1 年以上 7 經過セルモノ比較的全治者二多シ。此ノ事實 7 見ル二筒

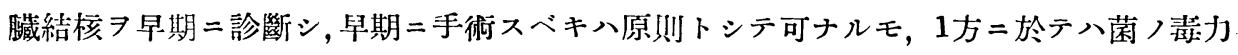

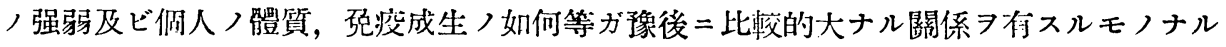
ヨ注意スルラ要ス。 